Folia primat. 1965;3:I-IV

\title{
Contents, Vol. 3, 1965
}

\section{CURATORES}

J. BIEGERT, Zurich W. C. OSMAN HILL, Atlanta, Ga. H. HOFER, Frankfurt a. M. J. PIVETEAU, Paris

A. H. SCHULTZ, Zurich D. STARCK, Frankfurt a. M. S. L. WASHBURN, San Francisco, Calif.

COLLABORATORES

E. L. BONE, Louvain

W. FIEDLER, Wien

H. J. HARLOW, Madison, Wis.

H. HEDIGER, Zurich

J. HÜRZELER, Basel

J. KÄLIN, Frihourg

J. R. NAPIER, London

A. REMANE, Kiel

W. L. STRAUS, Jr., Baltimore, Md.

H. ZAPFE, Wien

S. ZUCKERMAN, Birmingham

REDACTOR: J. BIEGERT, Zurich

Vol. 3

1965

\section{BASEL (Schweiz) S. KARGER NEW YORK}

Âlle Rechte, insbesondere das der Übersetzung in fremde Sprachen, vorbehalten

Ohne ausdrückliche Genehmigung des Verlages ist es auch nicht gestattet, dieses Buch oder Teile daraus

auf photomechanischem Wege (Photokopie $5 / 8$ Mikrokopie) zu vervielfältigen

(C)

Copyright 1965 by S. KargeГ AG, Basel

Printed in Switzerland by Schellenberg-Druck, Pfäffikon ZH

Cliches: Steiner \& Cie. AG, Base)

INDEX

Ankel, Friderun:

Der Canalis sacralis als Indikator für die Länge der Caudal-

region der Primaten 263

Bernstein, I. S.:

Activity Patterns in a Cebus Monkey Group 211 
Boelkins, R. C.: vide Hall, K. R. L.

Bourlière, F.: vide Petter-Rousseaux, A.

Broadhurst, P. L. and Jinks, J. L.:

Parity as a Determinant of Birth Weight in the Rhesus Monkey 201

Citters, Robert L. van and Lasry, James, E.:

Cardiovascular Function in Adult Baboons as Indicated by

Standard Diagnostic Tests 13

Conaway, C. H. and Sade, D. S.:

The Seasonal Spermatogenic Cycle in Free Ranging Rhesus

Monkeys

1

Gartlan, J. S.: vide Goswell, Marilyn, J.

Gordon, E. B.: vide Moor-Jankowski, J.

Goswell, Marilyn J. and Gartlan, J. S.:

Pregnancy, Birth and Early Infant Behaviour in the Captive

Patas Monkey Erythrocebus patas

189

Goswell, M. J.: vide Hall, K. R. L.

Guthrie, C. B.: vide Moor-Jankowski, J.

Hall, K. R. L.; Boelkins, R. C. and Goswell, M. J.:

Behaviour of Patas Monkeys, Erythrocebus patas, in Captivity, with Notes on the Natural Habitat

22

Jensen, G. D.: vide Kueiin, R. E.

Jinks, J. L.: vide Broadhurst, P. L.

Kaufmann, J. H.:

Studies on the Behavior of Captive Tree Shrews (Tupaia glis) 50

Kuehn, R. E.; Jensen, G. D. and Mohrill, R. K.:

Breeding Macaca nemestrina: A Program of Birth Engineering 251

Lasry, James, E.: vide Citters, Robert L. van

Malinow, M. R.:

Atherosclerosis in Subhuman Primates

277

Moor-Jankowski, J.; Wiener, A. S.; Gordon, E. B. and Guthrie, C. B.: Simian Blood Groups. A

«New» Blood Factor, Aba , of Celebes Black Ape Red Cells Demonstrated with Rabbit Antisera ... 245

Morrill, R. K.: vide Kuehn, R. E.

Petter-Rousseaux, A. et Bourlière, F.:

Persistence des phénomènes d'ovogénèse chez $\Gamma$ adulte de Daubentonia $\tau$ nadagascariensis

(Prosimii, Lemuriformes) . . . 241

Pilbeam, D. R.: vide Simons, E. L.

Sade, D. S.: vide Conaway, C. H.

Simons, E. L. and Pilbeam, D. R.:

Preliminary Revision of the Dryopithecinae (Pongidae, An-

thropoidea)

81

Sprankel, H.:

Untersuchungen an Tarsíus. I. Morphologie des Schwanzes

nebst ethologischen Bemerkungen 153

Wiener, A. S.: vide Moor-Jankowski, J.

Zenker, A.: 
Die pathologischen Veränderungen am Unterkiefer von Megaladapis edwardsi G. Grandidier

75

Current Literature - Neue Literatur - Nouveautés 233, 301

Book Review - Buchbesprechung - Livre Nouveau 225

Communication-Mitteilung 240 